\title{
The Upper Marine Limit in the Little Whale River area, New Quebec
}

\author{
DAVID R. ARCHER ${ }^{1}$
}

\begin{abstract}
The height of the upper marine limit as indicated by the lower limit of perched blocks was measured by altimeter at 21 sites. Analysis of these heights shows that the upper marine limit plane is tilted up towards $232^{\circ} \pm 36^{\circ}$. A further calculation of tilt was made by the inclusion of two levelled values obtained by Stanley (1939), and this gave a tilt up towards $277^{\circ} \pm 24^{\circ}$. The varied isostatic readjustment is believed to indicate a major centre of ice dispersal in the vicinity of southern Hudson Bay/northern James Bay, during the Wisconsin Glaciation.
\end{abstract}

RÉSUMÉ. La limite supérieure de la transgression marine dans la région de la Petite rivière de la Baleine, Nouveau-Québec. À l'aide d'un altimètre, on a mesuré en 21 sites l'altitude de la limite supérieure de la transgression marine, indiquée par la limite inférieure des blocs perchés. L'analyse de ces cotes d'altitude indique que le plan de la limite supérieure est relevé vers $232^{\circ} \pm 36^{\circ}$. En ajoutant deux mesures géodésiques obtenues par Stanley en 1939, on arrive à un relèvement dirigé vers $277^{\circ} \pm 24^{\circ}$. On peut croire que ce rajustement isostatique variable indique la présence d'un centre majeur de dispersion glaciaire wisconsinienne au voisinage du sud de la mer d'Hudson et du nord de la baie de James.

РЕЗЮМЕ. Верхнял гранича распространения морл в районе реки Литл Уэйл (Новый Квебек). Абсолютные отметки верхней границы распространения моря были измерены высотомером в 21 точке на основании нижней границы распространения висячих глыб. Анализ полученных данных показал, что плоскость верхней границы распространения моря наклонена вверх в сторону $232^{\circ} \pm 36^{\circ}$. Второй расчет наклона был произведен с введением двух значений, полученньх Станлеем в 1939 г., что дало значение наклона равное $277^{\circ} \pm 24^{\circ}$. Представляется, что ивменяющееся изостатическое перемещение указывает на существование крупного центра распределения льда во время Висконсинского оледенения в районах юэной части Гудвонова залива и северной части залива Джемс.

\section{INTRODUCTION}

Fluctuations in the relative level of the sea in the recent past are well documented in the landscapes of northern Canada by the existence of raised strandlines and emerged off-shore deposits with marine shells. However, the amount and chronology of these fluctuations in many areas remain unresolved, and their relationship to the last glaciation and deglaciation needs to be determined.

One area of particular interest is the coast-line in the vicinity of Little Whale River on the east coast of Hudson Bay (Fig. 1). In this area, relatively high land occurs in a number of places near the present coast, and this offers an especially good opportunity for the determination of the character of the emergence and of the variability of the upper marine limit. 


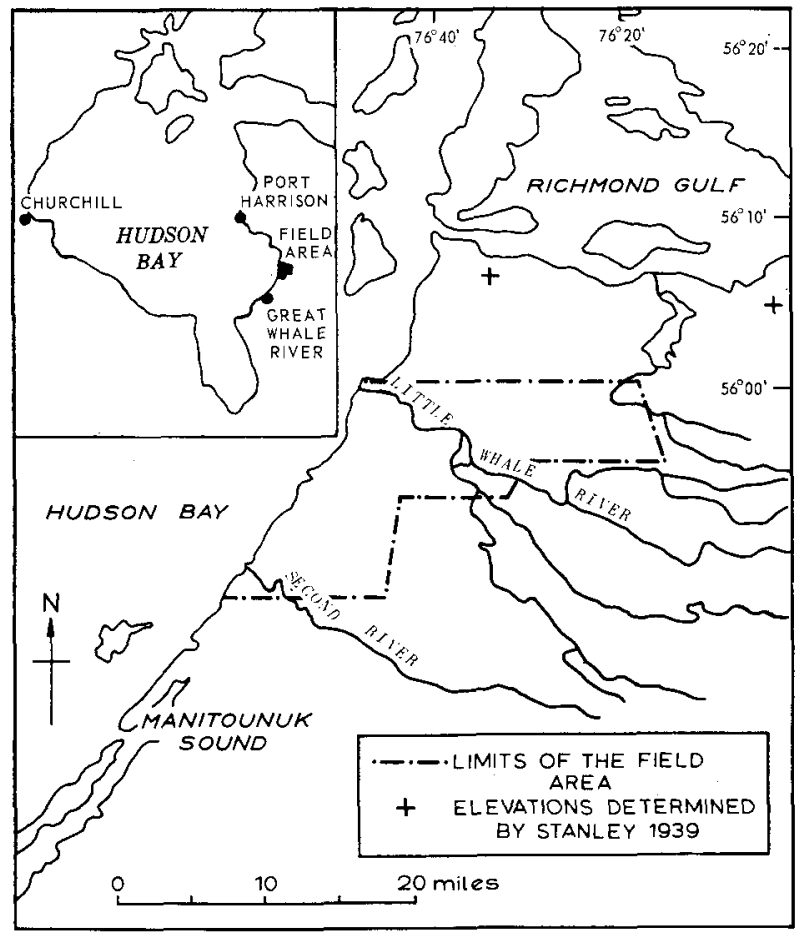

FIG. 1. General location of the field area.

It was in the adjacent area of Richmond Gulf (Fig. 1) that Stanley (1939) found the height of the upper marine limit at two points, and deduced from these that the sea level plane represented by them sloped upward toward Hudson Bay at a gradient of 3.3 feet per mile. He concluded that at one stage of the glaciation there was a centre of ice dispersal and of greatest ice thickness over Hudson Bay. This conclusion is supported by the evidence of Lee $(1959,1960)$, which showed that erratics were moved eastward in the Hudson Bay area.

The evidence, however, was inconclusive and the present study is an attempt to throw more light on the subject by the determination of the height of the upper marine limit at a number of places within a relatively small area, and hence to arrive at a more accurate estimate of the direction and tilt of the upper marine limit plane.

\section{THE AREA}

The field area extends northwards along the coast of Hudson Bay from $55^{\circ} 49^{\prime} \mathrm{N}$. to $56^{\circ} 01^{\prime} \mathrm{N}$. a distance of some 20 miles; the tract of land studied extended up to 8 miles inland. The major physiographic elements are a cuesta of Proterozoic sediments, basaltic flows and sills extending an average of 5 miles from the coast, and the mammilated granite which forms the eastern part of the area.

In the higher areas, glacial erosion has left a smoothed striated bedrock surface. The striae and associated crescentic gouges display an ice movement which 
was generally east to west (Archer 1966). This is in accord with the general pattern of deglaciation over the Labrador Ungava Peninsula (Ives 1960), and may be related to a centre of ice dispersal in the middle of that area. Glacial depositional features are rare, as they are generally covered by great thicknesses of marine deposits.

\section{METHODS AND INSTRUMENTAL ERRORS}

Paulin altimeters were used to determine heights. For the first two traverses the 'leap-frog' method was put into effect, but after this one altimeter became unserviceable, and the single altimeter had to be used. In these cases it became necessary to determine the changing barometric pressure within the field area by extrapolation from the continuous pressure records at Great Whale River and Port Harrison; surface weather charts at intermediate synoptic hours (every 3 hours) showed the trend of isobars within the area. Corrections for temperature were made for all values.

If the variations in pressure prevalent during the traverses are considered, the resulting error is thought to be of the order of \pm 10 feet on the escarpment (values $\mathrm{A}$ to $\mathrm{K}$ ) and \pm 25 feet in the east (values $\mathrm{L}$ to $\mathrm{X}$ ). See Table 1 and Fig. 2.

TABLE 1. The Upper Marine Limit.

\begin{tabular}{rll} 
A. & A. 876 feet \\
B. 913 feet & B. 913 feet \\
C. 907 feet & C. 900 feet \\
D. 893 feet & D. \\
E. & E. 889 feet \\
F. 931 feet & F. 923 feet \\
G. 938 feet & G. \\
H. 928 feet & H. \\
I. 929 feet & I. 912 feet \\
J. 943 feet & J. 937 feet \\
K. 925 feet & K. \\
L. 917 feet & L. 894 feet \\
M. 883 feet & M. 879 feet \\
N. 879 feet & N. 879 feet \\
O. 885 feet & O. 865 feet \\
P. 878 feet & P. \\
Q. 835 feet & Q. \\
R. 872 feet & R. \\
S. 852 feet & S. \\
T. 875 feet & T. \\
U. 861 feet & U. \\
V. 878 feet & V. \\
W. 863 feet & W. \\
X. 871 feet & X. \\
\hline
\end{tabular}




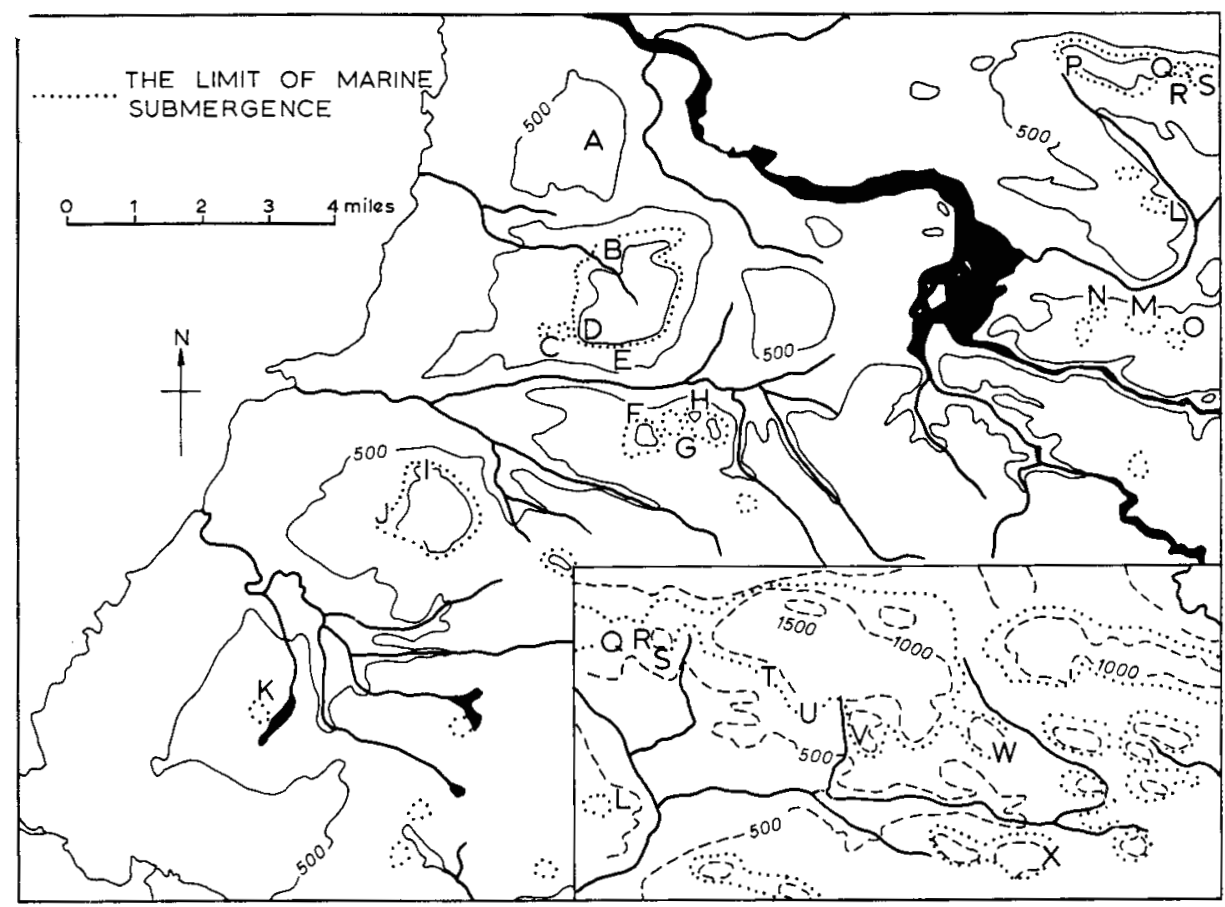

FIG. 2. The upper marine limit. A to $X$ are sites measured by altimeter (see Table 1). The map was compiled from provisional maps, Surveys and Mapping Branch, Department of Mines and Technical Surveys, Canada. Inset is extension eastward from main mapped area, from vertical air photographs.

This aneroid error may be expressed as a percentage of the marine limit elevation as approximately \pm 1 per cent on the escarpment and \pm 3 per cent in the eastern area.

Four different base levels were used in the traverses. In each case, a record was made of high and low tide over a number of days and the mean calculated. It is thought that in spite of the changes in tidal regime, the mean values, especially when averaged over a number of days, will not differ significantly from place to place. In addition, the highest tidal range observed was 7 feet, except under storm conditions. The error here is probably less than 1 foot.

\section{THE EVIDENCE}

Three features were measured to estimate the height of the upper marine limit:

1) The highest pebble or boulder ridges which are the characteristic marine strandline form in the area.

2) The lower limit of perched boulders, which represents the limit of wave action and is often visible as a sharp line of demarcation. (Bird 1954, 1959; Sim 1960).

3) The highest marine shells. The evidence in this case was inconclusive. Marine life may not have become abundant until some time after the emergence 
began. The shells frequently indicated a limit several hundreds of feet below that suggested by other evidence.

The second method was found to be of the greatest value, and it has been used here exclusively in the determination of tilt of the upper marine limit plane. However, on rather steep slopes, perched blocks may not be in sufficient abundance to provide a completely reliable estimate.

The lower limit of perched blocks can represent either the highest effective action of the waves or the highest action of ice-push. Normally, where ice-push acts at a higher level than storm waves it will give rise to ice-push ridges at its landward limit. Since none of these was observed in the area, it would seem that the perched block limit represents the highest limit of the erosive activity of waves when the sea was at its highest level. This probably includes the effects of prolonged westerly gales associated with high spring tides, the effect varying according to the position, exposure and relief of the coast. Assuming that tidal flow in the postglacial sea was similar to that of the present, exposed sites would have been affected under certain conditions to heights of 10 to 12 feet above normal high level spring tides. In contrast, some sites further inland, especially those on the east sides of hills, would have been well protected, and removal of perched blocks may only have occurred to a height of 4 feet above high spring tides. That this is so along the present coast is shown by the distribution of lichens above the present high water mark (Archer 1966).

Thus the variation resulting from a single sea level plane is probably of the order of 8 feet where perched blocks are numerous, whereas the error may be increased considerably at certain inland sites where perched blocks are less abundant.

The summation of instrumental and observational errors is probably \pm 20 feet on the escarpment and \pm 40 feet inland ( \pm 2 per cent and \pm 4 per cent of the marine limit elevation respectively).

\section{REGIONAL VARIATION IN THE UPPER MARINE LIMIT}

The character of the upper marine limit at each of the sites shown (Fig. 2) was examined in detail and followed for some distance in order to obtain values of maximum accuracy. The heights of the lower limit of perched blocks and the upper limit of beach ridges are shown in Table 1.

The hill at $\mathrm{A}$ appears to have been completely submerged. A boulder ridge occurs within a few feet of the summit ( $881 \mathrm{feet}$ ), and this was measured by Stanley (personal communication 1966) at 876 feet. Elsewhere, along the dip slope of the basalt escarpment ( $B$ to $K$ ), the upper marine limit is well defined with ridges of rounded boulders frequently in close juxtaposition to perched blocks (Fig. 3). The scarp slope is everywhere too steep to have permitted the accumulation of either perched blocks or boulder ridges. The granite hills at $F$, $\mathrm{G}$ and $\mathrm{H}$ (Fig. 2) have fairly steep sides, and it was only in limited localities that reliable estimates of the lower limit of perched blocks could be obtained.

The inland measurements of the height of the upper marine limit were made west of the embayment of Little Whale River to a distance of 20 miles from the 


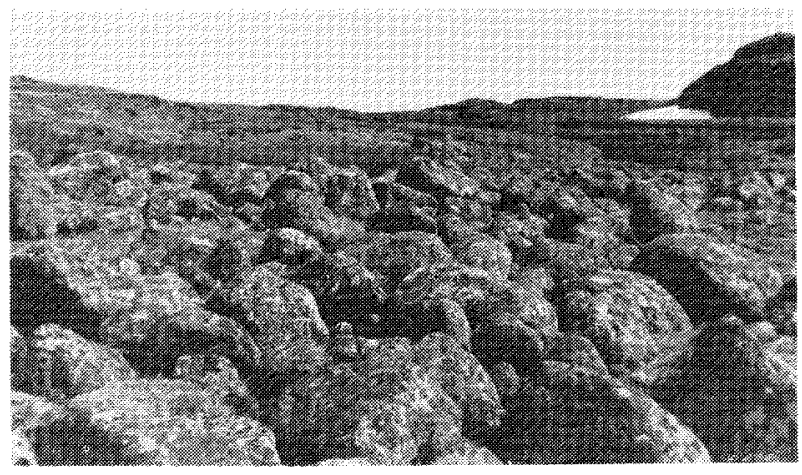

FIG. 3. The upper marine limit at $\mathrm{J}$ - a littoral boulder ridge in the foreground and a scatter of perched blocks in the background.

coast. All the sites (except L) were on granite hills and presented similar conditions. All were measured on moderately steep slopes of 10 to 20 degrees on which perched blocks were numerous. There is one particularly anomalous value (Q) where the measurement of 835 feet may have been an observational error due to material which had fallen from a higher level on a fairly steep slope. This value has been disregarded in the calculation of tilt. Raised beaches were less common than on the scarp and heights could be determined at relatively few places. None of these was sufficiently close to the lower limit of perched blocks to be noted here.

\section{SIGNIFICANCE OF THE VARIATION}

If it can be assumed that the measured values of the upper marine limit represent a single sea level plane, unaffected by residual ice, then the variations in height indicate a varied response to isostatic imbalance, and hence show a variable ice thickness covering the area. The assumption is supported by the absence throughout the field area of glacio-marine deposits. However, even if the marine limit is not truly synchronous, the time involved for retreat and wasting of residual ice would be sufficiently short in this area to make the assumption reasonably valid.

If, within the field area, the upper marine limit approximates a single plane, the lower limit of perched blocks is believed to give the most accurate indication of its variation. It is thought that in spite of the listed errors, there are sufficient values available to derive with some accuracy the maximum amount of tilt of the sea level plane and hence the slope of the former ice sheet.

The triangle method (Løken 1962) was used to plot the 21 measured points, and values of maximum tilt were obtained. Those triangles with narrow acute angles or short sides were disregarded. The derived mean value of the direction of maximum tilt was $232^{\circ} \pm 36^{\circ}$. The heights were plotted graphically height to distance (Fig. 4A) and a regression equation and a correlation coefficient obtained along this line. These are as follows:

$$
\mathrm{Y}=-4.23 \mathrm{x}+941.7 \quad(\mathrm{r}=-0.89)
$$

The correlation is significant at the .001 level. 


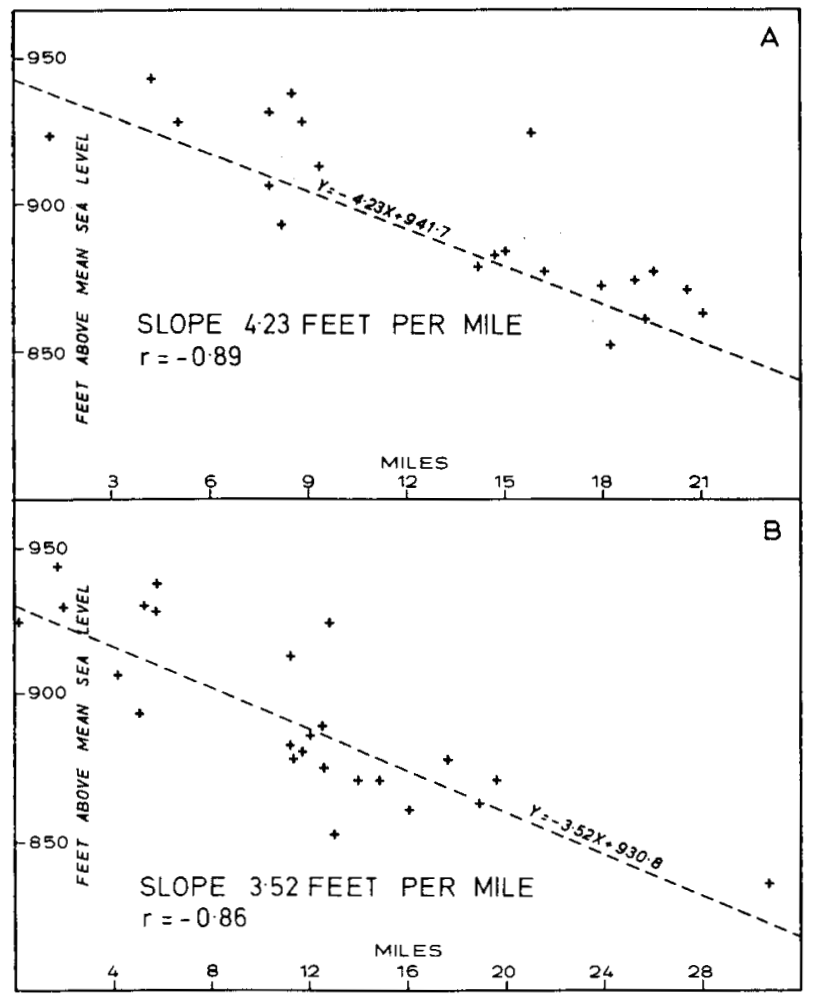

FIG. 4. The slope of the upper marine limit plane. A: based on the lower limit of perched blocks and a direction of maximum slope of $232^{\circ}$, B: based on a slope of $277^{\circ}$ and including sites at Richmond Gulf.

An additional determination of the slope of the upper marine limit was made by the inclusion of two accurately levelled values of Stanley (Fig. 1) (personal communication 1966) of the lower limit of perched blocks on the south coast of Richmond Gulf. In this calculation only those triangles that included one or both of the points levelled by Stanley were used. Plotting gave the mean greatest slope along the line $277^{\circ} \pm 24^{\circ}$ (Fig. 4B). This line yielded the regression:

$$
\mathrm{Y}=-3.52 \mathrm{x}+930.8 \quad(\mathrm{r}=-0.86)
$$

This is again significant at the .001 level.

It is apparent that the results show considerable variation in the gradient and direction of the maximum slope. When the line $232^{\circ}$ is projected from the field area, it passes through the middle of James Bay and south toward Lake Superior, whereas the line $277^{\circ}$ crosses the south end of Hudson Bay. There are three possible explanations of this variation and the factors may be acting individually or in some combination.

1) The values obtained by Stanley (1939) may not be synchronous with those of the present study.

2) The heights obtained by altimeter may not have been sufficiently accurate to determine very accurately the amount and direction of tilt.

3) The tilt of the upper marine limit may, in fact, be variable over quite short distances.

However there is sufficient similarity in the results to derive some general 
conclusions. It is believed that the results confirm the existence of a centre of maximum uplift, and hence of greatest ice thickness and ice dispersal for part of the Wisconsin Glaciation in the general vicinity of northern James Bay/southern Hudson Bay. This is in the same general locality as that suggested by Farrand and Gajda (1962) who, however, based their conclusions on a set of nonsynchronous data, and somewhat to the north of that suggested by Daly (1934). Since the heights included here are the highest upper marine limits yet obtained for North America, this centre of ice dispersal was probably not far distant from the actual field area.

Presumably this centre represents an earlier stage than the one which is well documented for the centre of the Labrador Ungava Peninsula (e.g. Ives 1960). This late glacial centre was sufficiently strong to affect the orientation of microtopographic features to the limits of the peninsula, as exemplified in the Little Whale area. It gave rise to a focus of uplift over the Schefferville area, as indicated by field work in the centre and eastern part of the peninsula, but it was not strong enough to affect the overall pattern of isostatic readjustment in the vicinity of Hudson Bay.

\section{ACKNOWLEDGEMENTS}

This research was made possible by a generous field grant from the Centre d'Etudes Nordiques at Université Laval. The McGill Sub-Arctic Research Laboratory provided surveying and camping equipment. I am indebted to Dr. W. P. Adams, former director of the Laboratory, to Dr. J. T. Parry of McGill University, and to Dr. N. Stephens of Queen's University, Belfast, for helpful advice while writing this paper.

\section{REFERENCES}

ARCHER, D. R. 1966. Deglaciation and postglacial emergence in the Little Whale River area, New Quebec - a preliminary report. McGill Sub-Arctic Research Papers, 21: 1-17.

BIRD, J. B. 1954. Postglacial marine submergence in central Arctic Canada. Geological Society of America Bulletin, 67: 457-64.

- 1959. Recent contributions to the physiography of northern Canada. Zeitschrift fur Geomorphologie, B3: 151-74.

DALY, R. A. 1934. The Changing World of the Ice Age. New Haven: Yale University Press, $271 \mathrm{pp}$.

FARRAND, W. R. and R. T. GAJDA. 1962. Isobases on the Wisconsin marine limit in Canada. Geographical Bulletin, 17: 5-22.

IVES, J. D. 1960. The deglaciation of Labrador Ungava - an outline. Cahiers de Géographie de Québec, 8: 323-43.

LEE, H. A. 1959. Eastward transport of erratics from Hudson Bay. Geological Society of America Bulletin, 70: 219-22.

- 1960. Late glacial and postglacial Hudson Bay sea episode. Science, 131: 1609-11.

LøKEN, 0. 1962. The late glacial and postglacial emergence and the deglaciation of northernmost Labrador. Geographical Bulletin, 17: 23-56.

SIM, v. w. 1960. Maximum postglacial marine emergence in northern Melville Peninsula. Arctic, 13: 178-93.

STANLEY, G. M. 1939. Raised beaches on the east coasts of James and Hudson bays (abstract). Geological Society of America Bulletin, 50: 1936. 